\title{
Cebus apella (Primata: Cebidae) as a New Host for Fonsecalges johnjadini (Acari: Psoroptidae, Cebalginae) with a Description of Anatomopathological Aspects
}

\author{
Luciana Guerim/ ${ }^{+}$, Gilberto Salles Gazêta*, Nicolau Maués Serra-Freire*, \\ Lilian Marques de Sá**, José Luis Catão Dias**
}

\begin{abstract}
Laboratório de Parasitologia Veterinária, Medicina Veterinária, Universidade Estácio de Sá, Estrada Boca do Mato 850, 22783-320 Rio de Janeiro, RJ, Brasil *Laboratório de Ixodides, Departamento de Entomologia, Instituto Oswaldo Cruz-Fiocruz, Rio de Janeiro, RJ, Brasil **Departamento de Patologia, Faculdade de Medicina Veterinária e Zootecnia, Universidade de São Paulo, São Paulo, SP, Brasil
\end{abstract}

Mites collected from the auditory canal of Cebus apella (capuchin monkey), family Cebidae, were identified as Fonsecalges johnjadini (Psoroptidae, Cebalginae). It is the first record of this parasite from this monkey. This paper emphasizes the importance of clinical and anatomopathological examinations for parasitic diagnosis in wild animals.

Key words: Cebus apella - Fonsecalges johnjadini - Cebalginae - Cebidae

Primates belonging to the genus Cebus are medium sized animals distributed from the north of South America to north of Argentina, inhabiting chiefly the Amazon rainforest and Atlantic rainforest in Brazil. This group of Cebidae is arboricolous and can live in any kind of neotropical rainforest (Freese \& Oppenheimer 1981). Each group of these monkeys consists of 8 to $18 \mathrm{mem}$ bers (Kuhlhorn 1939 apud Freese \& Oppenheimer 1981). The female is the first source of food, protection and carriage for the nestling. The young remain attached to the mother's back for up to the 6th or 7th week after birth (Nolte \& Ducker 1959 apud Freese \& Oppenheimer 1981) and are not wholly independent until between five and six months old (Freese \& Oppenheimer 1981). Their social behaviour, therefore, allows the easy spread of mites among the group.

To date, the mite species Cebalgoides cebi, Cebalges gaudi and Saimirioptes hershkovitzi have been found on the capuchin monkey (C. apella).

The aims of this paper are to record C. apella as a new host for the mite Fonsecalges johnjadini and to emphasize the importance of a detailed clinical and anatomopathological examinations to detect these parasites.

\section{MATERIALS AND METHODS}

A female capuchin monkey about 45 days old was captured in a free market in the State of São

\footnotetext{
${ }^{+}$Corresponding author. Fax: $+55-21-590.3545$. E-mail: guerim@ioc.fiocruz.br

Received 8 February 2000

Accepted 27 December 2000
}

Paulo and sent to the Technical Department of Veterinary and Biology of Fauna. The female remained isolated in captivity for 37 days. During this period, the animal presented a light ophthalmic itching, neurological signs and symptoms that needed corticosteroid, anticonvulsive, antibiotic and support treatment. The clinical outcome was death. The carcass was submitted for necropsy and for anatomopathological examinations at the Wild Animals Comparative Pathology Laboratory in the Pathology Department of São Paulo University. The necropsy revealed a certain quantity of brownish earwax containing mites in both ears. The mites were collected, arranged between slides of glass, fixed in ethanol $70^{\circ} \mathrm{GL}$ and sent to the Ixodides Laboratory IOCFiocruz, Rio de Janeiro, for identification. Fragments from all organs including the outer ear were collected, fixed in a packed $10 \%$ solution of formalin and embedded in histological paraffin wax. Sections about $5 \mu \mathrm{m}$ thick were stained in hematoxylin and eosin.

To prepare specimens for identification, male and female mites were cleared in lactophenol and mounted in creosote-Canada balsam. The material was examined under optical light microscopy (40x, 100x, 400x). The material preserved in ethanol $70^{\circ} \mathrm{GL}$ was deposited in the Ixodological Collection of the Ixodides Laboratory under the registration number: ACA-PSO no. 001.

\section{RESULTS}

The young capuchin monkey died from Enterococus faecalis septicemia caused by a nonsuppurative meningitis and an incomplete fusion 
of the skullcap resulting in pseudocele formation. The histological analysis of the inner surface of the auricula showed a discrete epiderm hyperplasia and an orthokeratotic keratosis associated with the presence of mites among the keratin fragments (Fig. 1) beyond discrete segmented areas of hypergranulosis. Occasional periglandular mononuclear cells, sebaceous gland and follicle enlargement were observed in the subjacent conjunctive tissue. In its outer surface, mites were found in the lumen of the enlarged hair follicles. At the dermic region of the posterior limb (Fig. 2), at the hairy region of the lower lips (Fig. 3), as well as at the other undetermined dermic regions, the following were also observed: a discrete epidermical hyperplasia, an orthokeratotic keratosis with or without segments of parakeratotic keratosis, multifocal pigmentary effusion areas, a discrete inflamatory infiltration by lymphocytes, macrophage and mastocyte migration into the surrounding dermical tissues and the presence of ectoparasites in the dilated hair follicles.

The mites were identified Fonsecalges johnjadini Fain, 1963 acording to Fain (1963a, b, c, 1966).

\section{DISCUSSION}

Mites belonging to the genus Fonsecalges have been found on a few neotropical primates, i.e.: sagüi-de-tufo-branco (Callithrix jacchus), sagüi (Saguinus nigricollis), both belonging to the Family Callitrichidae, and mico-de-cheiro (Saimiri sciureus) belonging to the Family Cebidae
(O'Connor 1987). With the present record, it is possible to include another host.

In respect of the site of parasitism, Fain (1963a) stated that $F$. johnjadini was found under crusts removed from the skin of $C$. jacchus. In 1963 Fain also refers to lesions on body, members, head and in the interior of the ears, either living freely or underneath superficial scales (Fain 1963c). The injuries the present authors observed at the dermic region of the pelvic appendage, at the hairy region of the lower lips and at other regions presenting epidermical hyperplasia and orthokeratotic keratosis could have been produced by $F$. johnjadini parasitism. In any case it is clear that detailed clinical and anatomopathological examination is important for the correct diagnosis of symptoms. In this study, the mites were collected from both right and left auricula and many mites were removed from the earwax characterizing these sites, indicating that they were a favorite habitat for these mites in this species of primate.

In conclusion, $C$. apella (Primate: Cebidae) is a host for $F$. johnjadini (Psoroptidae: Cebalginae). The mite is found in the auricula and surely they were found in other regions of the skin.

\section{REFERENCES}

Fain A 1962. Diagnoses d'acariens nouveax. Rev Zool et Bot Afric 66: 154-162.

Fain A 1963a. Nouveaux acariens psoriques parasites de marsupiaux et de singes sud-américains (Psoralgidae: Sarcoptiformes). Bull Ann Soc Royal d'Entomol Belg 99: 322-332.

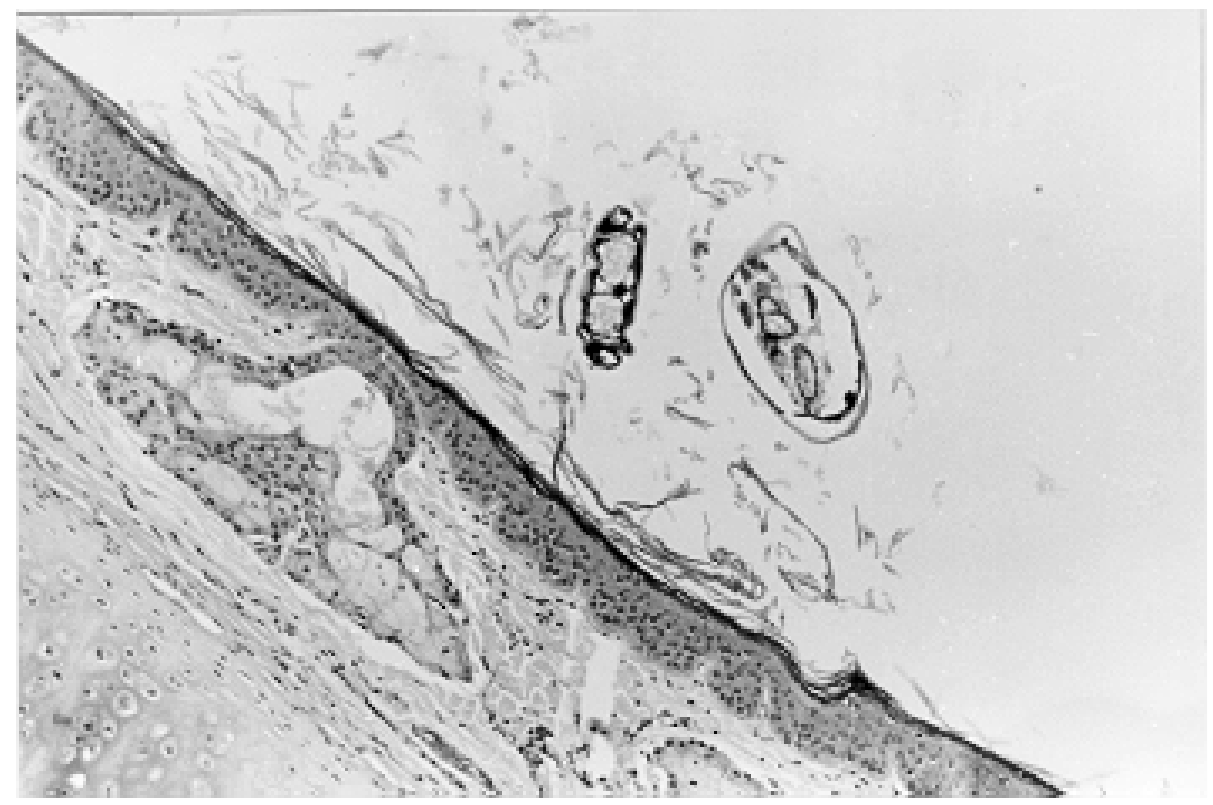

Fig. 1: histological section of the auricula (Cebus apella) with a discrete epiderm hyperplasia and an orthokeratotic keratosis associated with a presence of mites (Fonsecalges johnjadini), (40X). 


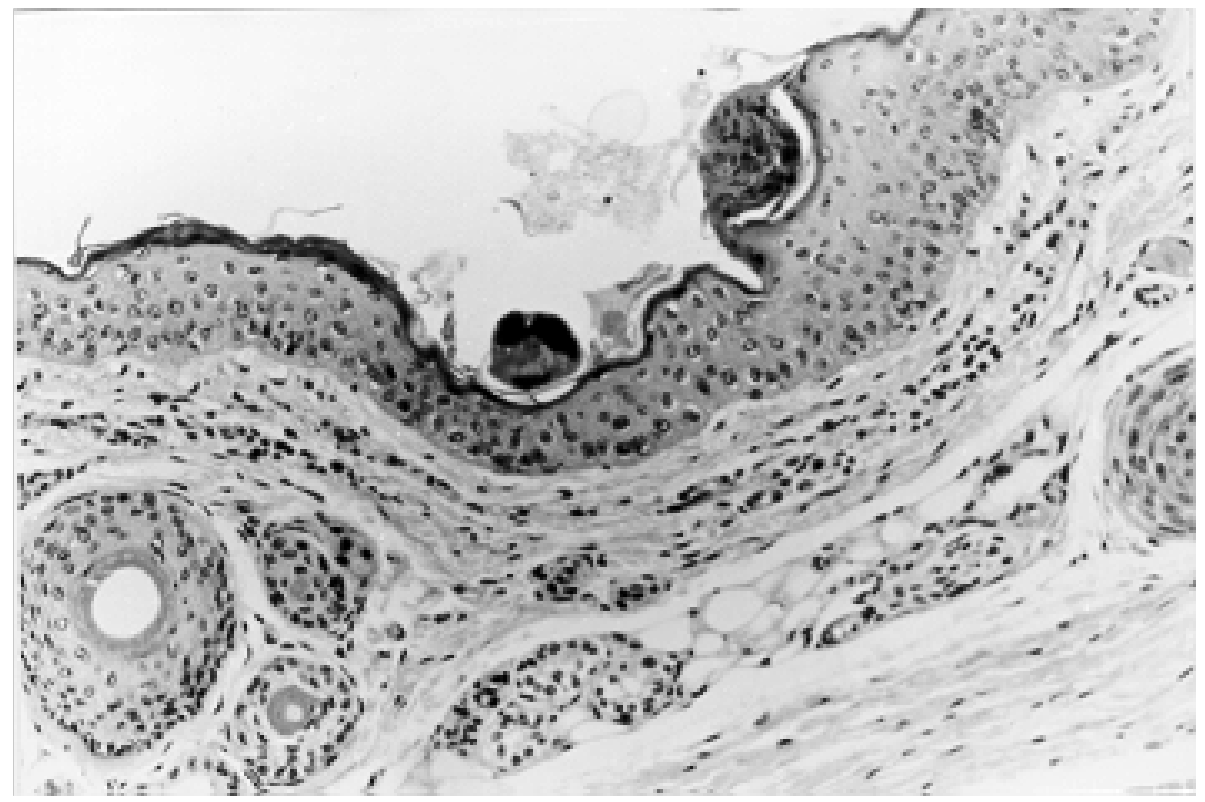

Fig. 2: histological section at the dermic region of the posterior limb (Cebus apella) showed ectoparasites (Fonsecalges johnjadini) in the lumen of the enlarged hair follicles (100X).

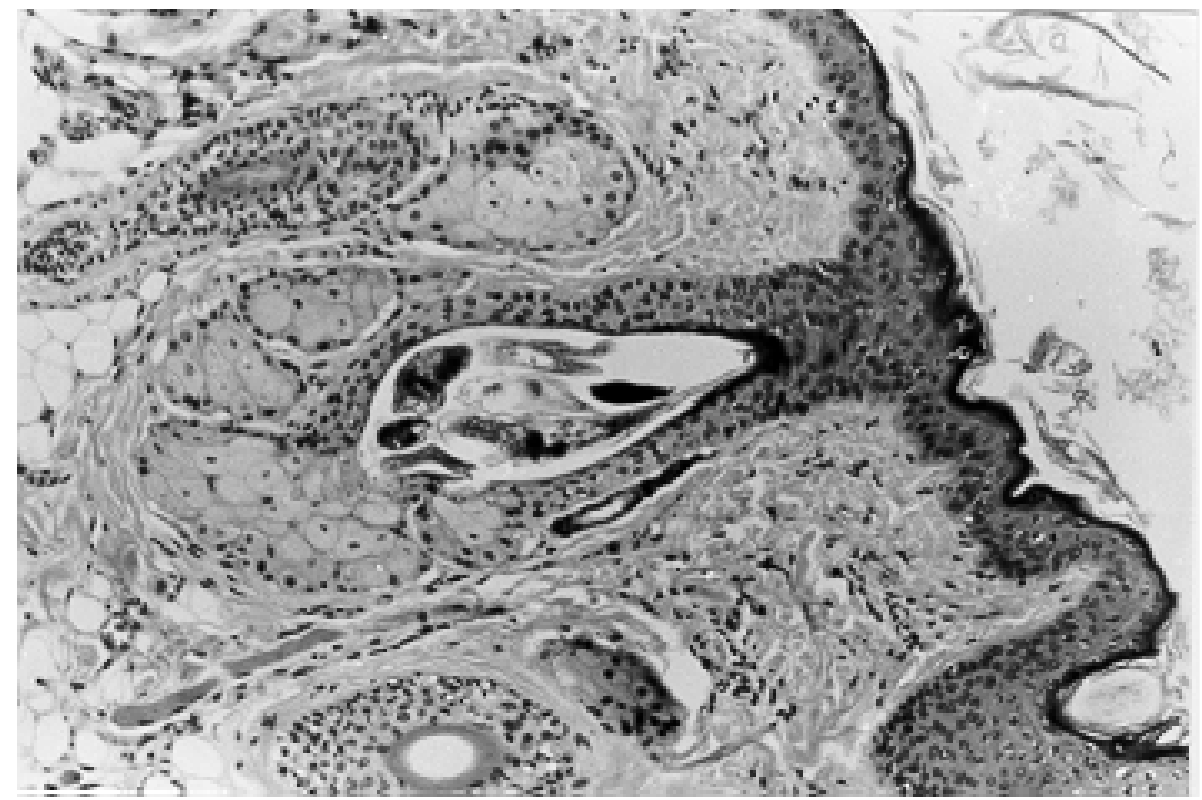

Fig. 3: histological section at the hairy region of the lower lips (Cebus apella) with a discrete epiderm hyperplasia and an orthokeratotic keratosis with the presence of mites (Fonsecalges johnjadini) in the lumen (100X).

Fain A 1963b. Un nouvel acarien producteur de gale chez un singe sud-américan. Bull Ann Soc Royal d'Entomol Belg 99: 467-470.

Fain A 1963c. Les acariens producters de gale chez les lémuriens et les singes avec uné étude des Psoptidae (Sarcoptiformes). Bull Inst Royal Sci Natur Belg 39: $1-125$.

Fain A 1966. Les acariens producters de gale chez le lémuriens et les singes II. Nouvelles observations avec description d'uné espèce nouvelle. Acarologia
8: $95-114$.

Freese CH, Oppenheimer JR 1981. The capuchin monkeys, genus Cebus. In J Nolte, C Ducker (eds), Ecology and Behaviour of Neotropical Primates, Academia Brasileira de Ciências, Rio de Janeiro, p. 331-390.

O’Connor BM 1987. Host associations and coevolutionary relationships of astigmatid mite parasites of New World primates I. Families Psoroptidae and Audyocoptidae. Field Zool 39: 245-260. 